\title{
Identifying specific social challenges of rare diseases: current challenges and issues
}

\author{
Dorica Dan ${ }^{1,2,3,4^{*}}$, Raquel Castro ${ }^{3}$ \\ From 7th European Conference on Rare Diseases and Orphan Products (ECRD 2014)
}

\section{Background}

EURORDIS Care Survey program conducted with over 12000 patients in 23 countries (2002-2008) has concluded that «social security systems are usually designed around common diseases and are not flexible enough to take into consideration unprecedented health needs» [1] and has provided a few insights into rare diseases (RD) patients and families social challenges. Further data collection and literature review is needed in order to assess more accurately these social challenges.

\section{Objective}

To compile information on social challenges of RD patients and their families.

\section{Method}

The identification of challenges is performed based on a literature review of:

- Communication from the Commission on Rare Diseases: Europe's Challenges (2008) [2];

- Council Recommendation on an Action in the Field of Rare Diseases (2009) [3];

- Communication from the Commission: European Disability Strategy 2010-2020 (2010) [4];

- EUROPLAN Report on 15 National Conferences (2010-2011) [5];

- EURORDISCare Survey Programme (2002-2008);

- 'Rare Diseases: Addressing the Need for Specialised Social Services and Social Policies' [6].

\section{Results}

Main social challenges identified:

- Lack of long term, funded and sustainable policies and structures at national level for the integration of patients with RD into social services and policies;

\footnotetext{
*Correspondence: dorica.dan@eurordis.org
}

${ }^{1}$ Romanian National Alliance for Rare Diseases, Zalau, Romania

Full list of author information is available at the end of the article
- Weak coordination between health and psychosocial complementary care, between central and regional/local infrastructures, leading to a consequent lack of multidisciplinary holistic approach;

- Lack of systems to accurately evaluate patients' disability degree and consequent lack of adequate compensation measures;

- Lack of information and understanding of patients' disabilities and corresponding implications in patients'/ families' daily lives;

- Lack of training of social sector professionals to deal with rare, complex cases, resulting in unprepared services/structures and insufficient sharing of best practices;

- Scarcity of social services and social policies/benefits. Difficulties in accessing services;

- Lack of case managers guiding patients/families to access the different types of care and structures;

- Lack of personalised/flexible measures and policies;

- Lack of measures to remove burden from family in daily care;

- Lack of systems to deal with transition from adulthood to childhood and ageing.

\section{Conclusion}

To improve the access from RD patients/families to adequate and high quality social policies and services there is a need to address these current social challenges by shaping national policies and implementing solutions at MS level. Guiding principles to address some of these challenges are currently being compiled within the European Committee of Experts on Rare Diseases Join Action Work Package 6.

\footnotetext{
Authors' details

${ }^{1}$ Romanian National Alliance for Rare Diseases, Zalau, Romania. ${ }^{2}$ Romanian Prader-Willi Association, Zalau, Romania. ${ }^{3}$ European Organisation for Rare Diseases - EURORDIS, Paris, France. ${ }^{4}$ European Commission Expert Group on Rare Diseases - DG Health and Consumers, Brussels, Belgium.
} 


\section{References}

1. EURORDIS: The Voice of 12,000 Patients. Paris: EURORDIS; 200922.

2. European Commission: Communication from the Commission to the European Parliament, the Council, the European Economic and social Committee and the Committee of the Regions on Rare Diseases: Europe's challenges,. 2008, COM(2008) 679.

3. European Council: Council Recommendation of 8 June 2009 on an action in the field of Rare Diseases., (2009/C 151/02).

4. European Commission: Communication from the Commission to the European Parliament, the Council, the European Economic and Social Committee and the Committee of The Regions: European Disability Strategy 2010-2020: A Renewed Commitment to a Barrier-Free Europe, 2010, COM(2010) 636.

5. EUROPLAN: European Project for Rare Diseases National Plans Development: Final Report - Main results of the 15 EUROPLAN National Conferences. 2011, Document may be downloaded from the EUROPLAN website (http://www.europlanproject.eu/).

6. EUCERD Joint Action: Rare Diseases: Addressing the Need for Specialised Social Services and Social Policies. 2012, Document may be downloaded from the EUCERD website (http://www.eucerd.eu/).

doi:10.1186/1750-1172-9-S1-029

Cite this article as: Dan and Castro: Identifying specific social challenges of rare diseases: current challenges and issues. Orphanet Journal of Rare Diseases 2014 9(Suppl 1):O29.

\section{Submit your next manuscript to BioMed Central} and take full advantage of:

- Convenient online submission

- Thorough peer review

- No space constraints or color figure charges

- Immediate publication on acceptance

- Inclusion in PubMed, CAS, Scopus and Google Scholar

- Research which is freely available for redistribution

Submit your manuscript at www.biomedcentral.com/submit
C Biomed Central 